\title{
OS USOS DO FACEBOOK NAS MANIFESTAÇÕES DOS SIMBOLISMOS ORGANIZACIONAIS
}

\author{
Camila Uliana Donna \\ ca_uliana@hotmail.com \\ Universidade Federal do Espírito Santo - Vitória, ES / Brasil \\ Alfredo Rodrigues Leite da Silva \\ alfredoufes@gmail.com \\ Universidade Federal do Espírito Santo - Vitória, ES / Brasil
}

http://dx.doi.org/10.1590/1413-2311.0282013.42999

Recebido em 08/07/2013

Aprovado em 29/07/2014

Disponibilizado em 01/12/2014

Avaliado pelo sistema double blind review

Revista Eletrônica de Administração

Editor: Luís Felipe Nascimento

ISSN 1413-2311 (versão on-line)

Editada pela Escola de Administração da Universidade Federal do Rio Grande do Sul.

Periodicidade: Quadrimestral

Sistema requerido: Adobe Acrobat Reader.

\section{RESUMO}

Este artigo tem o objetivo de compreender a relação entre os usos do Facebook pelos membros do jornal on-line XYZ e as manifestações dos simbolismos organizacionais. Para contextualizar o caminho adotado para tratar do objetivo foram articuladas contribuições teóricas sobre interacionismo simbólico, interpretativismo e simbolismo organizacional. Tais contribuições baseiam a discussão de que a interação social, a comunicação e os usos do Facebook estão relacionados entre si no cotidiano organizacional. A partir dessa relação no cotidiano, diferentes grupos sociais elaboram construções simbólicas com o potencial de marcar o contexto organizacional. Parte-se do entendimento de que isso ocorre na medida em que os simbolismos construídos interferem nas articulações entre os próprios grupos sociais nas organizações. O método qualitativo norteou a abordagem empírica neste estudo. A coleta de dados foi realizada mediante pesquisa bibliográfica e documental, netnografia e entrevistas semiestruturadas. O tratamento dos dados se deu por meio da análise de conteúdo, na modalidade temática. Após a análise, observou-se que o Facebook é um canal de trocas simbólicas entre os sujeitos na organização, porém, nessa mídia, essas trocas são veladas. Evidenciou-se um entendimento compartilhado de que no Facebook há muita exposição e por isso as pessoas têm medo de postar informações pessoais ou sobre o trabalho, pois acreditam estar sendo vigiadas. Nesse contexto, outras redes sociais digitais também foram identificadas como veículo de troca de conteúdos simbólicos.

Palavras-Chave: Simbolismo Organizacional; Interpretativismo; Interacionismo Simbólico; Redes Sociais Digitais; Facebook; Netnografia.

\section{USES OF FACEBOOK IN MANIFESTATIONS OF ORGANIZATIONAL}

REAd | Porto Alegre - Edição 79 - N 3 - setembro/dezembro 2014 - p. 681-712 
Os usos do Facebook nas manifestações dos simbolismos organizacionais

\title{
SYMBOLISMS
}

\begin{abstract}
This paper aims to understand the relation between the uses of Facebook by members of the online newspaper XYZ and the manifestations of organizational symbolisms. In order to contextualize the approach adopted to deal with the objective, theoretical contributions on symbolic interactionism, interpretivism and organizational symbolism were articulated. Such contributions are the basis to the discussion according to which social interaction, communication and the uses of Facebook are related to each other in the organizational routine. From this relationship in daily life, different social groups elaborate symbolic constructions with the potential to mark the organizational context. We start from the understanding that this occurs to the extent that the built symbolisms interfere in the articulations between the social groups in the organizations. The qualitative method guided the empirical approach in this study. Data collection was performed by literature and desk research, netnography and semi-structured interviews. The data were treated by content analysis, in the thematic mode. After analysis, it was observed that Facebook is a channel of symbolic exchanges between individuals in the organization, however, in that media, these exchanges are veiled. It became evident the existence of a shared understanding that, on Facebook, there is a lot of exposure which is why people are afraid to post personal information or information about their jobs, because they believe they are being watched. In this context, other digital social networks have also been identified as means for exchanging symbolic content.
\end{abstract}

Keywords: Organizational Symbolism; Interpretivism; Symbolic Interactionism; Digital Social Networks; Facebook; Netnography.

\section{USOS DE FACEBOOK EN LAS MANIFESTACIONES DE SIMBOLISMOS ORGANIZACIONALES}

\begin{abstract}
RESUMEN
Este artículo tiene como objetivo comprender la relación entre los usos de Facebook por miembros del periódico on-line XYZ y manifestaciones de simbolismos organizacionales. Para contextualizar el enfoque adoptado para tratar de los objetivos fueron articulados aportes teóricos sobre el interaccionismo simbólico, interpretativismo y el simbolismo organizacional. Dichas contribuciones se basan en el análisis de que la interacción social, la comunicación y los usos de Facebook están relacionados entre sí en la rutina organizacional. A partir de esta relación en la vida diaria, los diferentes grupos sociales elaboran construcciones simbólicas con el potencial de marcar el contexto organizacional. Partido es el entendimiento de que esto ocurre en la medida en que los simbolismos construidos interfieren en las articulaciones entre los grupos sociales propias en las organizaciones. Lo método cualitativo guían el enfoque empírico en este estudio. La recolección de datos fue realizada por la investigación bibliográfica y documentos, netnografia y entrevistas semi -estructuradas. El análisis de datos se realizó a través del análisis de contenido, en la modalidad temática. Tras el análisis, se observó que Facebook es un canal de intercambios simbólicos entre los individuos dentro de
\end{abstract}

REAd | Porto Alegre - Edição 79 - Nº 3 - setembro/dezembro 2014 - p. 681-712 
la organización, sin embargo, que los medios de comunicación, estos intercambios son velados. Se hizo evidente que un compartir en Facebook y hay una gran cantidad de exposición para entender por qué las personas tienen miedo de publicar información personal o sobre el trabajo porque creen que están siendo vigilados. En este contexto, otras redes sociales en línea también han sido identificadas como un vehículo para el intercambio de contenido simbólico.

Palabras clave: Simbolismo Organizacional; Interpretativismo; Interacción Simbólica; Redes sociales digitales; Facebook; Netnografia.

\section{INTRODUÇÃO}

Este artigo tem como objetivo compreender a relação entre os usos do Facebook pelos membros do jornal on-line XYZ e as manifestações dos simbolismos organizacionais. A relevância dessa discussão se baseia no entendimento de que as organizações são formadas por pessoas que interagem entre si simbolicamente (MORGAN; FROST; PONDY, 1983; TURNER, 1990), por meio de processos comunicacionais (GIOIA, 1986) que recebem influências dos usos das novas tecnologias de comunicação, a serem ainda investigadas.

A investigação da relação entre os processos comunicacionais, a construção do ambiente humano e as tecnologias não é algo novo. Já na década de 1960, McLuhan e Fiore (1969) e McLuhan (1971), ao estudarem os meios de comunicação, destacavam que gradualmente as tecnologias criam novos ambientes humanos. Os autores não se referiam, obviamente, à internet nem às redes sociais digitais que conhecemos hoje, mas às tecnologias desenvolvidas até aquele momento, tais como a tipografia, a fotografia, o rádio, o telefone, a televisão, entre outras. Entretanto, eles já as concebiam dentro de uma lógica pela qual reconheciam a articulação dessas tecnologias na era da eletrônica, quando se "estabelece uma rede global que tem muito do caráter de nosso sistema nervoso central [...] [que] constitui um campo único e unificado de experiência” (MCLUHAN, 1971, p. 390).

O foco deste artigo se aproxima desse entendimento, ao tratar de uma rede social digital específica e contemporânea, o Facebook. Ele é aqui entendido como uma tecnologia capaz de articular os processos comunicacionais na construção do ambiente humano, com implicações simbólicas no contexto organizacional. Na medida em que se observou a pouca atenção concedida a essa temática nos estudos organizacionais, buscou-se, com este artigo, contribuir para preencher tal lacuna.

Para alcançar o objetivo proposto, foram utilizadas as contribuições teóricas de Blumer (1969), Morgan, Frost e Pondy (1983), Gioia (1986) e Turner (1990) acerca de interacionismo

REAd | Porto Alegre - Edição 79 - N 3 - setembro/dezembro 2014 - p. 681-712 
Os usos do Facebook nas manifestações dos simbolismos organizacionais

simbólico, interpretativismo e simbolismo organizacional, descrevendo-se seus principais elementos e conceitos, a fim de compreender as relações e processos simbólicos que se estabelecem no cotidiano das organizações. As ideias desses autores, em conjunto com os trabalhos de Maines (1977), Mendonça (2002), Marchiori (2009) e Carvalho (2010), permitem compreender a relação da interação social que ocorre dentro e fora da organização com os processos de comunicação entre os indivíduos.

Na discussão sobre como se dá a interação e a comunicação entre os sujeitos pesquisados, utilizaram-se os estudos de Boyd e Ellison (2007), Ellison, Steinfield e Lampe (2006, 2007), Dwyer, Hiltz e Passerini (2007), Nadkarni e Hofmann (2012) e Golder, Wilkinson e Huberman (2007) para descrever o uso das redes sociais digitais como ferramenta de comunicação e, especificamente, os usos que os indivíduos fazem do Facebook.

Em conjunto, essas contribuições teóricas permitiram tratar do seguinte problema de pesquisa: como o uso do Facebook no cotidiano das pessoas dentro e fora do jornal on-line $\mathrm{XYZ}$ articula-se às manifestações dos simbolismos organizacionais?

A abordagem empírica adotada para tratar do problema em questão, legitimar as articulações teóricas e aprofundar a discussão em tela baseou-se no método qualitativo. A coleta dos dados foi realizada mediante pesquisa bibliográfica e documental, netnografia e entrevistas semiestruturadas. O tratamento de dados se deu por meio da análise de conteúdo (BARDIN, 2002), na modalidade temática (MINAYO, 1999).

A escolha do locus contou com a interação virtual prévia de um dos autores do artigo com os membros da organização por meio do Facebook. Além disso, o fato de os indivíduos atuarem em um jornal on-line e utilizarem a internet como ferramenta de trabalho foi determinante. Os sujeitos de pesquisa atuam nos níveis operacional e estratégico do jornal online XYZ e utilizam o Facebook para interagir socialmente.

Para desenvolver a presente discussão, o artigo foi estruturado da seguinte maneira: a discussão do embasamento teórico está dividida em dois tópicos relacionados entre si, dos quais se assinala que o primeiro tópico trata das articulações entre os temas simbolismo organizacional, interacionismo simbólico e os usos das redes sociais digitais, e o segundo tópico se volta para os usos de redes sociais digitais nas organizações e como esses usos se relacionam com a interpretação dos símbolos; em seguida, é descrita a metodologia utilizada na investigação empírica; por fim, os dados coletados são confrontados com as contribuições teóricas articuladas e são apresentadas as considerações finais do artigo.

REAd | Porto Alegre - Edição 79 - N 3 - setembro/dezembro 2014 - p. 681-712 


\section{OS SIMBOLISMOS E AS REDES SOCIAIS DIGITAIS}

Neste artigo, optou-se pela abordagem do interacionismo simbólico baseada em Blumer (1969). Segundo Carvalho (2010), ela possibilita a compreensão da forma como os atores interpretam a realidade na qual estão inseridos (ações, objetos, pessoas) e como essa interpretação influencia o comportamento individual desses atores.

Ou seja, essa abordagem está relacionada com o processo de interpretação - não só dos elementos simbólicos, mas também da ação dos indivíduos. De acordo com Godoy (1995), o interacionismo simbólico considera fundamentais os sentidos que os indivíduos dão para algo, pois eles surgem a partir do processo de interação social.

As interações sociais se dão por intermédio de processos comunicacionais e simbólicos (GIOIA, 1986). Esses processos permitem aos indivíduos gerar e transmitir informações e significados (MORGAN; FROST; PONDY, 1983; CORRÊA, 2009). A comunicação é a base da interação social (MORGAN; FROST; PONDY, 1983; GIOIA, 1986; TURNER, 1990) e é por meio dela que os membros organizacionais se relacionam e produzem uma consciência da vida (BERGER; LUCKMANN, 1978; BRETAS, 2006).

O simbolismo organizacional permite, então, compreender as interações sociais entre os membros da organização, os sistemas de signos e símbolos que são criados e recriados nessas trocas e a forma como tudo isso cria a organização (MORGAN; FROST; PONDY, 1983; TURNER, 1990; JAIME JR., 2005).

Deve-se observar ainda que o processo de interpretação é amplo e implica a articulação de uma série de elementos. Turner (1990) diz que, para compreender uma organização, é necessário, antes, compreender estes elementos chamados por ele de rituais, tradições, cerimônias, mitos e símbolos. Alvesson e Berg (1992) afirmam que uma organização pode ser compreendida como um processo contínuo de construção social por meio desses elementos.

Para que os elementos presentes no cotidiano organizacional sejam entendidos, optou-se nesta pesquisa pela perspectiva interpretativista, pois, segundo Morgan, Frost e Pondy (1983), ela analisa a interpretação com base na atividade simbólica da vida humana. Os autores afirmam que a adoção dessa perspectiva facilita a compreensão de como os indivíduos criam sentidos para as diversas situações e de que forma elas se tornam realidades. Esses sentidos são criados por meio da compreensão de alguns elementos, entre eles, o símbolo. O conceito adotado aqui se baseia em Morgan, Frost e Pondy (1983), que consideram o símbolo como um sinal que expressa algo muito maior do que o propriamente dito.

REAd | Porto Alegre - Edição 79 - N 3 - setembro/dezembro 2014 - p. 681-712 
Os usos do Facebook nas manifestações dos simbolismos organizacionais

A construção de sentidos ocorre em torno de símbolos, por meio da comunicação. Como explica Marchiori (2009, p. 294), a comunicação nas organizações permite a construção de significados, ela "envolve, afeta e constrói a realidade de uma organização”. Pela comunicação, as pessoas se transformam e transformam seus ambientes. Tal entendimento baseia a perspectiva do interacionismo simbólico (MAINES, 1977).

Ao tratar da transformação do ambiente pela via da comunicação, McLuhan (1971) destaca o papel das tecnologias nesse processo. Essas tecnologias são diversas, tais como a roda, a caligrafia, a tipografia, o rádio, a televisão, entre muitas outras, e todas consideradas meios de comunicação. Entre esses meios estão aqueles que, na década de 1960, eram considerados como novas tecnologias, da era da eletrônica, como a televisão, com o potencial de transformar o mundo no que o autor chamou de uma aldeia global. Para McLuhan (1971, p. 112), no lugar das antigas estruturas sociais, que exigiam a existência de um centro para influenciar as margens, em virtude dessas novas tecnologias, a civilização "subitamente está experimentando uma reunificação instantânea de todas as suas partes mecanizadas em um todo orgânico. Este é o mundo novo da aldeia global”.

A eletrônica passa a permitir a propagação da consciência humana pelo mundo inteiro, desenhando um futuro para civilização no qual “a natureza do homem está sendo traduzida rapidamente em sistemas de informação, que produzem uma grande sensibilidade global e nenhum segredo” (MCLUHAN; POWERS, 1993, p. 13). Deve ficar claro que o potencial de transformação dos meios de comunicação relacionados com a eletrônica se baseia nos próprios meios. McLuhan e Fiore (1969) explicam que o conteúdo da comunicação tem menos impacto nas sociedades do que a natureza do meio. Os autores citam, como exemplo desse impacto da tecnologia eletrônica, o efeito das televisões, que levam ao envolvimento e à integração da sociedade mediante um intenso comprometimento das pessoas.

Para destacar o que articula esses efeitos, McLuhan (1971) classifica como do tipo cool o meio de comunicação que leva a um maior comprometimento, diferenciando-o do tipo hot:

- o do tipo cool é o mais envolvente, pois tem baixa definição. A baixa definição significa que há poucas informações para os sentidos humanos envolvidos por ele, portanto a pessoa precisa preencher por conta própria o que falta, levando a sociedade ao comprometimento e à integração em torno do meio;

- o do tipo hot se aprofunda em um único sentido humano e tem alta definição. A alta definição indica que esse meio satura o sentido humano com os dados, não 
deixando muito espaço para a pessoa preencher algo que esteja faltando, o que leva à fragmentação da sociedade em torno do meio.

O autor cita vários exemplos de meio cool, tais como o diálogo, o telefone e a caricatura, em contraponto ao livro, ao rádio e à fotografia, que são exemplos de meio hot. Segundo McLuhan e Fiore (1969), em diferentes intensidades, de acordo com o grau de integração e fragmentação que têm o potencial de produzir, esses meios são vistos como um prolongamento dos sentidos do ser humano. Esses meios têm impactos na maneira de a pessoa pensar e agir sobre o mundo, pois cada ambiente que é concebido é, ao mesmo tempo, o meio pelo qual e o cenário para o qual o mesmo homem que o criou define para si um papel. Essa inter-relação fica clara quando se trata da internet, criada pelos homens e entendida aqui como um meio cool por intermédio do qual definimos um novo ambiente social. Nesse ambiente, o homem redefine seus papéis, tais como ver, ouvir, escrever, filmar, reclamar, elogiar...; é também um meio que se desdobra em outros meios cool, tais como as redes sociais digitais.

As redes sociais digitais são compreendidas aqui como "uma rede de computadores que conecta uma rede de pessoas” (GARTON; HAYTHORNTHWAITE; WELLMAN, 1997). É por meio da comunicação e do simbolismo que as redes sociais digitais são utilizadas pelos indivíduos no cotidiano de diversas formas, entre as quais cabe destacar três grandes grupos:

- usos para integrar interesses em comum. Nesses casos, percebe-se o uso como mobilização social (RHEINGOLD, 1993; CASTELLS, 1999; PEREIRA, 2010; SHIRKY, 2011). O foco aqui tende a ser a promoção de relacionamentos, sejam afetivos ou antissociais (WELLMAN, 1996). Os interesses podem envolver também troca de informações relacionadas a transações comerciais e ao consumo (ALBUQUERQUE; PEREIRA; BELLINI, 2011);

- usos para o trabalho em rede (WELLMAN, 1996). O contexto digital permite que os indivíduos acessem recursos (WEBER, 1997) e informações (CONSTANT; SPROULL; KIESLER, 1996; WELLMAN, 1996; CORRÊA, 2009). Esses usos para o trabalho, nas organizações, têm implicações diversas, desde a potencialização na obtenção de recursos necessários até a queda de produtividade (CARDOSO, 2009) e o vazamento de informações estratégicas da organização na rede (OLIVEIRA JUNIOR, 2011);

- usos relacionados ao acesso ao poder, para legitimá-lo (RIBEIRO, 2000) ou dar voz aos membros organizacionais “marginalizados” (SPROULL;

REAd | Porto Alegre - Edição 79 - N 3 - setembro/dezembro 2014 - p. 681-712 
Os usos do Facebook nas manifestações dos simbolismos organizacionais

KIESLER, 1991; CORRÊA, 2009). O protagonismo facilitado pelas redes sociais digitais pode ser visto como uma ameaça para gestores, que optam por proibir o uso delas dentro da organização (OLIVEIRA JUNIOR, 2011).

Esses três conjuntos de usos percebidos - integração de interesses em comum, trabalho em rede e acesso ao poder - estão interligados e têm impactos sociais, políticos e econômicos na sociedade e nas organizações. Castells (1999, p. 69) fala desses impactos e destaca que as novas tecnologias da comunicação - entendidas aqui como as redes sociais digitais - "não são simplesmente ferramentas a serem aplicadas, mas processos a serem desenvolvidos”.

Percebe-se então, concordando com Castells (1999), que o compartilhamento de informações entre diferentes indivíduos é o aspecto central da lógica de redes. De acordo com o autor, essa lógica está presente em todos os tipos de atividades, contextos e locais, desde que os envolvidos estejam conectados eletronicamente.

Entre as diversas redes sociais digitais, este artigo escolheu tratar dos sites de redes sociais, definidos por Boyd e Ellison (2007) como sistemas que permitem aos indivíduos criarem perfis públicos, compartilharem uma lista de usuários com quem eles tenham conexão e verem as conexões das outras pessoas. Os autores afirmam ainda que, além de permitirem novas conexões, esses sites permitem a articulação de redes de contatos já existentes.

Haythornthwaite (2005) chama esses contatos de laços latentes - aqueles indivíduos que têm algum tipo de ligação off-line e que utilizam os sites de redes sociais para a manutenção desses laços. Esta pesquisa se volta exatamente para esse fenômeno: membros organizacionais que interagem socialmente dentro e fora de uma mesma organização e que, além da comunicação cotidiana, utilizam os sites de redes sociais para se comunicar.

\section{OS SITES DE REDES SOCIAIS NAS ORGANIZAÇÕES E A INTERPRETAÇÃO DOS SÍMBOLOS}

Ao utilizarem os sites de redes sociais como um elemento da comunicação no contexto organizacional e fora dele, os indivíduos realizam o compartilhamento de valores e significados, e são esses significados compartilhados que fazem as pessoas agirem (VERGARA; CALDAS, 2005). Ou seja, ao analisar os processos comunicacionais pela via do simbolismo organizacional (MORGAN; FROST; PONDY, 1983), torna-se possível compreender como os sites de redes sociais estão sendo usados para compartilhar significados e de que forma o meio influencia a interpretação destes.

REAd | Porto Alegre - Edição 79 - N 3 - setembro/dezembro 2014 - p. 681-712 
Entre os diversos sites disponíveis atualmente, optou-se, nesta pesquisa, em focar o Facebook, e uma das justificativas para essa escolha é o fato de essa rede ter sido concebida e estruturada para a manutenção de contatos já existentes (ELLISON; STEINFIELD; LAMPE, 2007). Além disso, os usos das redes sociais digitais identificados em pesquisas anteriores (ELLISON; STEINFIELD; LAMPE, 2007; BOYD; ELLISON, 2007) estão diretamente relacionados aos usos do Facebook. Alguns autores focaram essa ferramenta em seus estudos e identificaram usos para a criação do capital social de "ponte” (ELLISON; STEINFIELD; LAMPE, 2007); para o acesso a oportunidades (ELLISON; STEINFIELD; LAMPE, 2006, 2007); para a comunicação e a manutenção de relações (DWYER; HILTZ; PASSERINI, 2007); para o entretenimento (ELLISON; STEINFIELD; LAMPE, 2006); e para a navegação em perfis de contatos (GOLDER; WILKINSON; HUBERMAN, 2007).

Ao agrupar os usos entre os relacionados aos aspectos individuais dos atores ou entre os relacionados aos aspectos da interação social, os usos de interesse dessa pesquisa são os do segundo grupo, do qual podemos destacar os seguintes elementos: a atenção aos aspectos subjetivos dos sujeitos, a interação social (GIOIA, 1986), os processos comunicacionais (MENDONÇA, 2002; MARCHIORI, 2009; CARVALHO, 2010) e a presença dos elementos da interpretação, entre eles os símbolos (MORGAN; FROST; PONDY, 1983).

Ao voltar ao problema proposto para esta pesquisa - como o uso do Facebook no cotidiano das pessoas dentro e fora do jornal on-line XYZ articula-se às manifestações dos simbolismos organizacionais? -, pode-se destacar que é pela via da compreensão dos usos do Facebook como ferramenta de comunicação que é possível analisar a articulação de sua utilização com as manifestações dos simbolismos organizacionais.

Todo esse processo ocorre dentro de um contexto social, que também é criado e continuamente reconstruído por meio das interações entre os indivíduos, ou seja, é socialmente construído (BERGER; LUCKMANN, 1978; BRETAS, 2006). É nesse contexto que as práticas cotidianas se realizam, consideradas nesse projeto como as interações sociais, as trocas simbólicas, os processos comunicacionais e os usos do Facebook.

Com base no que foi discutido até aqui é possível propor um esquema conceitual para investigações sobre a temática em tela, conforme ilustrado na Figura 1.

REAd | Porto Alegre - Edição 79 - N 3 - setembro/dezembro 2014 - p. 681-712 
Os usos do Facebook nas manifestações dos simbolismos organizacionais

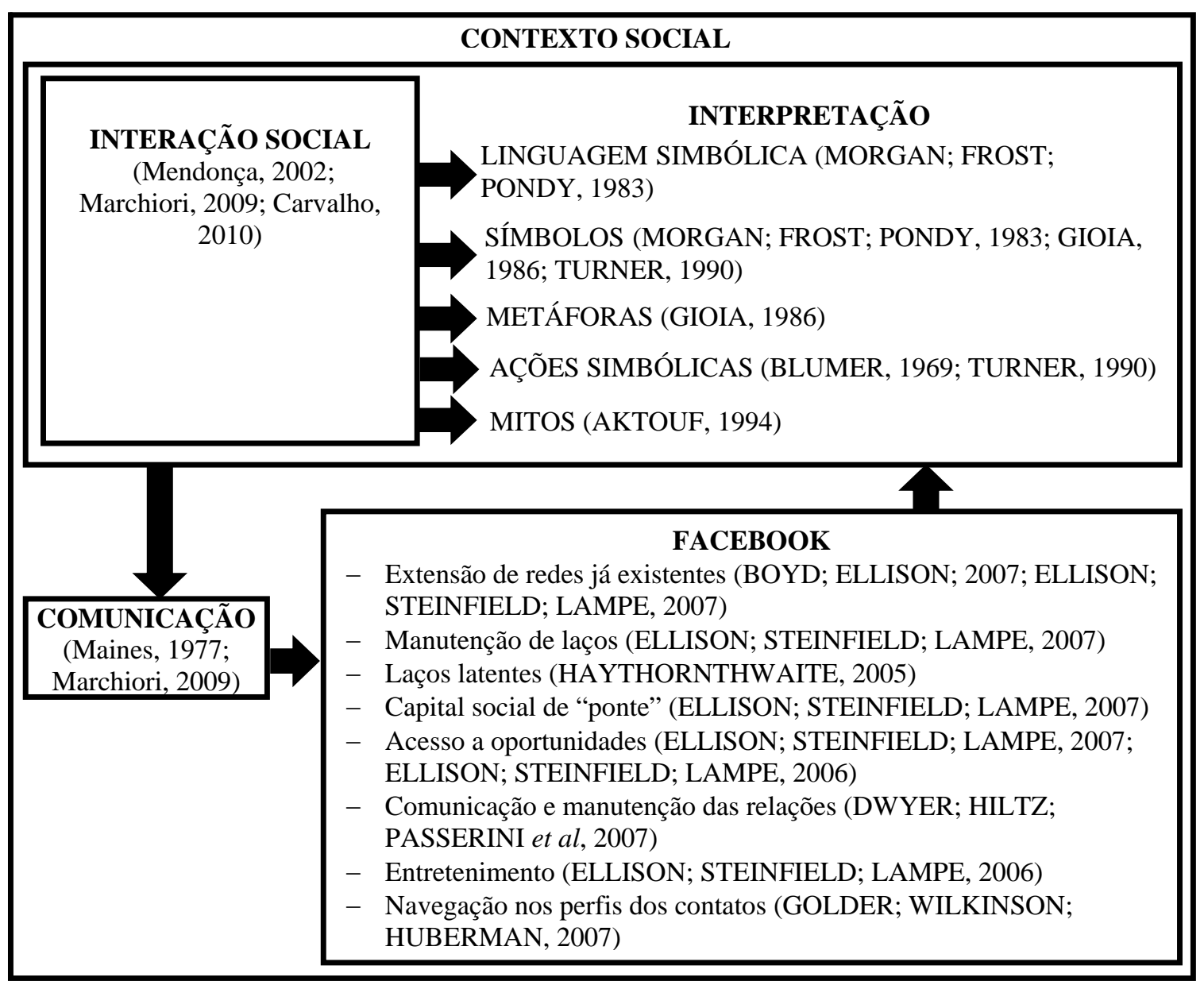

Figura 1 - Esquema conceitual proposto com base nas articulações teóricas realizadas. Fonte: Elaborada pelos autores.

Nesse esquema, as redes sociais se inserem em um processo de construção social contínuo com as seguintes etapas concomitantes: a) a interpretação que se dá por meio da interação social e da comunicação e envolve vários elementos, entre eles os símbolos; b) a interpretação responsável pela criação de significados tanto para esses elementos quanto para as ações dos indivíduos; c) a comunicação, por intermédio da qual esses significados são compartilhados. Deve ficar claro que existem diversas maneiras de se comunicar no contexto social e que são utilizadas para a construção social. Entretanto, diante da impossibilidade de tratar das infinitas formas de comunicação em uma organização, este estudo buscou ampliar a compreensão sobre esse fenômeno focando a comunicação via Facebook. As demais formas de interação estão inseridas em um contexto social mais amplo, colocado em posição central na Figura 1. A utilização do Facebook está diretamente ligada ao processo de interpretação, pois tanto a interação quanto a comunicação podem ocorrer no ambiente virtual.

Tomando como base o esquema conceitual acima descrito, foi realizada uma pesquisa empírica voltada para o problema de pesquisa proposto.

REAd | Porto Alegre - Edição 79 - N 3 - setembro/dezembro 2014 - p. 681-712 


\section{METODOLOGIA}

Para responder a questão proposta no problema - como o uso do Facebook no cotidiano das pessoas dentro e fora do jornal on-line XYZ articula-se às manifestações dos simbolismos organizacionais? -, foi utilizado o método qualitativo. A escolha do método foi baseada em Blumer (1969). Segundo o autor, na abordagem interacionista, adotada na presente pesquisa, o estudioso deve interagir ativamente com as pessoas que estão sendo pesquisadas. Por isso a coleta de dados foi feita por meio da netnografia e de entrevistas semiestruturadas baseadas em um roteiro. Além disso, foram utilizadas a pesquisa bibliográfica e a análise documental.

A escolha do locus se deu a partir de contatos prévios, via Facebook, com os sujeitos. Além disso, há de se ressaltar que o fato de o locus ser um jornal on-line foi um facilitador para que os sujeitos tivessem mais familiaridade com o Facebook e outras redes sociais digitais. O primeiro contato foi feito mediante uma reunião com o coordenador e com a editora-chefe do XYZ. Nesse momento, foram analisados documentos da organização nos quais constavam os dados pessoais de cada membro, o cargo ocupado e o tempo de serviço. O XYZ tem, atualmente, dez funcionários e dois estagiários. Optou-se, nesta pesquisa, por inserir todos os funcionários e excluir os estagiários. O principal critério utilizado para a definição dos sujeitos foi a interação social, e, pelo que se pôde observar durante as visitas à redação, os estagiários não interagem com os sujeitos escolhidos.

Após essa seleção, os dez sujeitos foram avisados de que participariam de uma pesquisa e, por isso, seriam adicionados à rede de contatos de um dos autores do artigo no Facebook, com o intuito de se iniciar a primeira etapa deste trabalho: a netnografia. No mesmo dia, os convites virtuais foram enviados e aceitos.

A netnografia é um método de coleta de dados produzidos em ambiente virtual. Segundo Kozinets (2010, p. 1), a "netnografia é uma forma especializada de etnografia adaptada às contingências da computação mediada do mundo social de hoje”.

É necessário deixar claro aqui que o procedimento netnográfico analisa apenas os processos comunicacionais voltados para a troca via internet de informações escritas. Para analisar o uso do Facebook e o processo de interação social de forma mais aprofundada e complementar, levando em consideração aspectos como a fala, o gestual e as relações sociais dos indivíduos fora da internet, foi utilizada a entrevista semiestruturada. As entrevistas semiestruturadas foram gravadas e transcritas.

Os dados foram tratados por meio da análise de conteúdo. De acordo com Bardin (2002,

REAd | Porto Alegre - Edição 79 - N 3 - setembro/dezembro 2014 - p. 681-712 
Os usos do Facebook nas manifestações dos simbolismos organizacionais

p. 38), a análise de conteúdo revela significados e significantes: “[...] pode ser considerada como um conjunto de técnicas de análise das comunicações que utiliza procedimentos sistemáticos e objetivos de descrição do conteúdo das mensagens”.

Entre as variações de análise do conteúdo existentes, adotou-se aqui a análise de conteúdo na modalidade temática. Nessa abordagem, segundo Minayo (1999), a partir dos dados identificam-se núcleos de sentido ou categorias de análise cuja presença signifique algo para o objetivo proposto. Neste artigo, são seis as categorias de análise observadas a partir dos dados coletados: interação social com colegas de trabalho e superiores; comunicação; elementos significantes; usos do Facebook; conteúdo das postagens; e relação entre o uso do Facebook e a organização. Essas categorias têm relação com as categorias de análise adotadas na netnografia: relacionamento e interação; conteúdos do trabalho ou pessoais; e manifestação simbólica. Ao longo da análise, os sujeitos de pesquisa foram identificados apenas pelo termo “Sujeito” seguido de um número, para preservar sua identidade.

A metodologia escolhida permitiu legitimar as articulações teóricas desenvolvidas nesta pesquisa. O presente estudo limitou-se a analisar um só contexto, mas, ao mesmo tempo, pode servir de base para que outras realidades sejam analisadas.

\section{SOBRE A ORGANIZAÇÃO}

O jornal on-line XYZ foi fundado em 2007, em uma capital da Região Sudeste, e faz parte de uma rede de comunicação. Essa rede ainda possui um canal de televisão e duas rádios. A estrutura do jornal on-line XYZ é igual à de um jornal impresso, com várias editorias (Geral, Política, Polícia, Economia, Entretenimento, Esportes e Social). Segundo os sujeitos de pesquisa, os gestores deixam muito claro que os negócios da rede devem ser rentáveis e, por conta disso, trabalham com equipes enxutas, salários baixos e redações integradas. Há ainda uma questão relacionada ao sindicato dos jornalistas, que faz fiscalizações periódicas quanto a horas extras. O jornalista que faz hora extra deve ser remunerado, por isso, nessa rede de comunicação, há um controle muito grande para que os funcionários não excedam seu horário de trabalho, para que a organização não tenha aumento na folha de pagamento.

A central de jornalismo está localizada na capital do estado e conta com um coordenador de jornalismo, uma editora-chefe, um analista de produto, quatro repórteres e três produtores web. Os salários decrescem nessa mesma ordem.

REAd | Porto Alegre - Edição 79 - N 3 - setembro/dezembro 2014 - p. 681-712 


\section{AS TROCAS SIMBÓLICAS E AS RELAÇÕES COM O USO DO FACEBOOK}

Com base nos dados coletados por meio da netnografia e das entrevistas semiestruturadas, procedeu-se à análise. Inicialmente foi descrita como se dá a interação social entre os indivíduos naquele contexto organizacional. Observou-se que a interpretação do cotidiano de trabalho reflete diretamente no significado compartilhado do contexto organizacional. Esse significado relaciona-se de maneira direta com a forma de uso que os sujeitos fazem do Facebook. Após descrever os usos, foi feita uma análise dos conteúdos simbólicos postados nessa mídia e observou-se que, por se tratar de um local de exposição, outras redes sociais digitais também são utilizadas em busca de maior privacidade. No fim da análise, descreveram-se as tensões relacionadas ao uso do Facebook e a relação delas com o objetivo do presente artigo.

\subsection{Interação social}

A interação entre colegas de trabalho e seus superiores está diretamente relacionada à quantidade de trabalho dos profissionais. Muitos dos sujeitos citam o excesso de trabalho como um fator que faz com que não haja muita interação entre os colegas.

1. “A gente tem muito trabalho aqui. Então, pra ficar conversando é meio complicado. Raramente a gente para pra conversar” (SUJEITO 9).

2. "tenho cinco ou seis pautas todos os dias pra apurar. E isso acaba sendo muito desesperador” (SUJEITO 8).

3. “existe um acúmulo de funções para a editora que é muito grave. Não tem como você operacionalizar, pensar e gerir. [...] E eu sinto que isso atrapalha o relacionamento de todos os funcionários com ela, de uma maneira geral” (SUJEITO 4).

De acordo com o último sujeito citado, a falta de interação gerada pelo excesso de trabalho pode estar se refletindo no relacionamento entre os membros da organização. Esse reflexo patenteia-se na fala da maioria dos sujeitos, quando destacam, durantes as entrevistas, uma relação estritamente profissional entre eles:

4. "Não tenho amigos pessoais aqui. Tenho colegas de profissão” (SUJEITO 6).

REAd | Porto Alegre - Edição 79 - N 3 - setembro/dezembro 2014 - p. 681-712 
Os usos do Facebook nas manifestações dos simbolismos organizacionais

5. "Eu acho que a gente tem um coleguismo, a gente troca conversa, mas não são pessoas que eu tenho muito hábito de trocar confidências, de falar da minha vida pessoal” (SUJEITO 4).

6. “Não há nenhum tipo de relação pessoal” (SUJEITO 3).

A dificuldade de interação relatada nas entrevistas está evidenciada na utilização do Facebook pelos membros da organização. Os dados colhidos na netnografia mostram que o relacionamento deles via redes sociais digitais é também muito restrito. Os comentários abaixo foram postados no Facebook juntamente com fotos dos colegas.

7. "Festa da redação! Aniversário da colega” (SUJEITO 5).

8. “Aniversário - farto - do [...], na redação!” (SUJEITO 9).

Ao mesmo tempo que se observa essa relação restrita ao contexto do trabalho, há um significado compartilhado de que, por causa do excesso de trabalho, um sujeito precisa do outro, e que o trabalho deles é interdependente. Esse fato está diretamente ligado ao que dizem Morgan, Frost e Pondy (1983) quando afirmam que os indivíduos criam sentidos para as situações e estes se tornam realidade.

9. “o meu trabalho depende do delas e o delas depende do meu” (SUJEITO 6).

10. “é preciso ter em mente que eu faço parte de uma equipe e cada decisão que eu tomo - pode ser um produtor, um estagiário - impacta na vida de todo mundo" (SUJEITO 1).

É importante notar que o significado de dependência mútua compartilhado entre os sujeitos faz com que haja um reconhecimento da importância do papel de cada membro naquele contexto. Esse fato está relacionado ao conceito de interacionismo simbólico, segundo o qual as pessoas agem com base no significado que os fatos têm para elas (VERGARA; CALDAS, 2005). O trecho abaixo, de uma das entrevistas, destaca isso:

11. "esse trabalho que a gente faz junto me motiva, me influencia muito" (SUJEITO 6).

Nos onze trechos de entrevistas ou de postagens do Facebook apresentados até agora, pode-se observar um processo simbólico de interpretação das ações (CARVALHO, 2010), ambíguo, que se configura da seguinte maneira: os sujeitos destacam o excesso de trabalho e a dificuldade que isso provoca na interação social dentro do ambiente de trabalho; em contrapartida, esse mesmo excesso de trabalho gera uma construção coletiva de interdependência entre os membros organizacionais. Essa construção vai ao encontro do

REAd | Porto Alegre - Edição 79 - Nº 3 - setembro/dezembro 2014 - p. 681-712 
entendimento de Vergara e Caldas (2005), que veem o cotidiano como um contexto no qual o indivíduo compreende o ambiente e atua de acordo com essa compreensão.

Nesse sentido, há postagens envolvendo colegas de redação também relacionadas ao conteúdo do trabalho:

12. "Sem dúvida, esse foi um dos trabalhos mais gostosos que eu já fiz. Tudo é mágico e lindo na maternidade e é sempre uma honra poder falar dos profissionais que fazem esse momento ser ainda mais especial” (SUJEITO 4).

Como um todo, as entrevistas e postagens no Facebook indicam a ausência de um relacionamento pessoal sem conotação direta com o trabalho entre os membros da organização, pois este surge norteando as interações mesmo quando se trata de questões pessoais, como o “aniversário” de um dos colegas. Para compreender melhor essa ausência de relacionamento pessoal sem relação com o trabalho entre os membros da organização, faz-se necessário analisar os usos do Facebook declarados pelos sujeitos.

\subsection{Os usos do Facebook}

Antes de começar a análise dos usos do Facebook, cabe relembrar que ele é uma extensão de redes já existentes em determinado contexto (BOYD; ELLISON, 2007). Dessa forma, todos os sujeitos informaram que não se relacionam com pessoas desconhecidas. Grande parte das informações coletadas, tanto na netnografia quanto nas entrevistas, sinaliza o uso com o intuito de comunicação e manutenção das relações (DWYER; HILTZ; PASSERINI, 2007), além de troca de informações sobre o próprio cotidiano por meio da navegação entre os perfis (GOLDER; WILKINSON; HUBERMAN, 2007).

13. "Eu acho que os comentários e as relações no Facebook são uma consequência das suas relações fora dele” (SUJEITO 10).

14. "Nos finais de semana que eu estou de folga, em casa, sem nada pra fazer, eu entro no Facebook e fico olhando a vida das pessoas” (SUJEITO 2).

Vale destacar que, de acordo com Subrahmanyam et al. (2008), o Facebook pode ser utilizado para reforçar conexões que, às vezes, não são muito fortes na vida real. Isso fica evidenciado na fala de um dos sujeitos, ao relatar o relacionamento entre colegas de trabalho via Facebook.

REAd | Porto Alegre - Edição 79 - N 3 - setembro/dezembro 2014 - p. 681-712 
Os usos do Facebook nas manifestações dos simbolismos organizacionais

15. "Eu acho que o Facebook influencia a relação entre eles, porque os ajuda a manter mais contato uns com os outros. Eu acho que se eu participasse mais, eu seria mais amiga deles” (SUJEITO 8).

Observaram-se também muitas citações entre os sujeitos de pesquisa de usos do Facebook conforme são descritos por Ellison, Steinfield e Lampe (2006), ou seja, relacionados a momentos de lazer e entretenimento, inclusive no horário de trabalho. Isso pode ser uma tentativa de fuga de um cotidiano caracterizado pelo excesso de trabalho, como foi evidenciado no XYZ.

16. “Facebook é mais o momento de descontração” (SUJEITO 4).

17. “Meu momento de lazer no trabalho é o Facebook” (SUJEITO 10).

Outro uso do Facebook muito citado entre os sujeitos analisados está relacionado ao cotidiano profissional. Shirky (2012) argumenta que, com o surgimento das redes sociais digitais, o jornalista tem acesso a informações postadas pelos usuários e identifica aquelas que mais os interessam. Dessa forma, o Facebook tem a função de pautá-lo.

18. “Dia que está chovendo demais, por exemplo, e as pessoas vão postando fotos de chuva, então a gente vai pegando, vai se informando, busca saber onde está alagado, o que está acontecendo. Então a gente pega informação, porque serve para o nosso trabalho" (SUJEITO 6).

19. “Eu vejo o que as pessoas estão falando muito e penso que rende pauta. [...] Tiro muita coisa de lá. E muita gente manda sugestão de pauta, inclusive pelo bate-papo" (SUJEITO 2).

Esses e alguns outros usos citados pelos sujeitos vão ao encontro de três valores citados por Recuero (2010) como relacionados com as redes sociais digitais: visibilidade, reputação e popularidade. Ao estabelecerem conexões com amigos e familiares, os indivíduos estão mais expostos, mais visíveis; os impactos desse aumento da visibilidade social se refletem na construção da reputação e da popularidade de determinada pessoa ou grupo. Um aspecto chave dessa dinâmica é a manutenção dos laços sociais, que estão diretamente relacionados com essa visibilidade e suas implicações (ELLISON; STEINFIELD; LAMPE, 2007). Os fragmentos empíricos, a seguir, evidenciam esse aspecto entre os sujeitos de pesquisa:

20. “veio o Facebook e fiz a página, pras pessoas me encontrarem, conhecerem minha história” (SUJEITO 1).

REAd | Porto Alegre - Edição 79 - N 3 - setembro/dezembro 2014 - p. 681-712 
Camila Uliana Donna \& Alfredo Rodrigues Leite da Silva

21. “As pessoas compartilham sobre como foi o dia delas. Querem saber do meu dia? Tá aqui, olha” (SUJEITO 4).

22. “Geralmente eu posto a matéria que escrevo. Acho bacana que as pessoas ali do meu círculo do Facebook, meus amigos, saibam” (SUJEITO 9).

Ainda sobre as manifestações citadas acima, um aspecto a se destacar é o uso do Facebook como um canal de comunicação e troca simbólica entre os sujeitos de pesquisa. Diante disso, cabe discutir melhor como se dá esse processo de comunicação.

\subsection{Comunicação}

Já é sabido que a interação social está diretamente relacionada com a comunicação entre indivíduos. Faz parte da experiência cotidiana, segundo Bretas (2006), os sujeitos utilizarem as interações midiáticas para construírem significados. Lyon (2002) também destaca que os relacionamentos mediados por algum tipo de tecnologia viabilizam a troca de conteúdos simbólicos. Dessa forma, em um contexto marcado pela carga excessiva de trabalho, os sujeitos adequaram o meio de comunicação à realidade. No caso do XYZ, a falta de tempo faz com que os funcionários utilizem algumas redes sociais digitais para se comunicar.

23. “[...] porque não dá tempo de ficar conversando, então a gente conversa muito pela chat. Não só questões profissionais, questões pessoais também, quando estamos chateadas com alguma coisa” (SUJEITO 8).

24. "Pro pessoal daqui [no XYZ], quando quer bater papo, é pelo chat mesmo" (SUJEITO 9).

Como se pôde perceber na fala dos sujeitos, o chat on-line é a rede social digital (GARTON; HAYTHORNTHWAITE; WELLMAN, 1997) mais utilizada pelos membros da organização e caracteriza-se por ser do tipo emergente (RECUERO, 2010).

No contexto analisado, as mensagens trocadas nas redes sociais digitais são múltiplas e não lineares, pois tratam de diferentes tipos de assuntos. Há também a flexibilização do tempo, visto que essas redes permitem trocas rápidas e, muitas vezes, não simultâneas, possibilitando relacionamentos entre pessoas em diferentes espaços e tempos. A virtualização dos relacionamentos se dá à medida que o excesso de trabalho dificulta o contato pessoal, levando os funcionários a utilizarem os meios digitais para se comunicar. O conteúdo dessas mensagens se mostra múltiplo. Tal multiplicidade já foi identificada por Corrêa (2009) ao destacar que, no contexto organizacional, as trocas comunicacionais que ocorrem em

REAd | Porto Alegre - Edição 79 - N 3 - setembro/dezembro 2014 - p. 681-712 
Os usos do Facebook nas manifestações dos simbolismos organizacionais

ambientes digitalizados assumem características específicas, como a multiplicidade e a não linearidade das mensagens, a flexibilização do tempo e a virtualização dos relacionamentos.

Dadas essas características, em virtude de o chat on-line permitir velocidade no envio e recebimento de mensagens, como em um diálogo (BOYD; ELLISON, 2007), ele se tornou um meio de comunicação utilizado não só para falar do conteúdo do trabalho, mas também para falar de assuntos pessoais e desabafos.

25. “O e-mail é pra falar coisas do trabalho mesmo. E quando é uma coisa mais pessoal, mais corriqueira, a gente usa o bate-papo, o chat” (SUJEITO 9).

26. “O chat é para alguma coisa mais íntima, fazemos comentários, críticas sobre colegas de trabalho, questões de trabalho que não queremos que ninguém ouça, ou desabafo” (SUJEITO 5).

27. "Medo de vazar o chat. No dia que vazar, vai ter demissão em massa neste lugar. Falamos sobre tudo mesmo, falamos até sobre o que não deveria” (SUJEITO 4).

Ao tratar desses conteúdos, é possível observar a presença de alguns elementos, denominados por Recuero (2010) de capital social. Para Coleman (2002), o capital social encontra-se no conteúdo embutido nas interações que constituem os laços sociais e pode ser acumulado, aprofundando um determinado laço e aumentando o sentimento de grupo.

Ou seja, a troca de conteúdos simbólicos viabilizada pelas redes sociais digitais cria laços sociais entre os membros da organização. Os conteúdos trocados, muitas vezes informações pessoais e desabafos, contribuem para a criação de conteúdos simbólicos referentes ao significado de pertencimento e grupo (NADKARNI; HOFMANN, 2012).

\subsection{Conteúdos simbólicos}

Os conteúdos pessoais e de desabafo em conversas realizadas utilizando, principalmente, o chat on-line, identificados por meio de netnografia e de entrevistas, estão relacionados aos temas excesso de trabalho, salário e problemas de gestão.

28. "É muito cansativo quando a gente trabalha no fim de semana: são doze dias sem folga. Então esse tipo de coisa, não é que desmotiva, mas faz você parar e pensar: 'nossa, e o resto? Família, namorado... então não tem natal, não tem dia das mães, dos pais, não tem nada!’” (SUJEITO 6).

REAd | Porto Alegre - Edição 79 - N 3 - setembro/dezembro 2014 - p. 681-712 
29. “[...] não acho justo eu trabalhar aqui há tantos anos e ganhar a mesma coisa que quem chegou aqui semana passada. Pra mim, uma questão clara de planos de cargos de salário que passou da hora de ter” (SUJEITO 4).

30. “A direção da empresa cobra bastante da gente, mas eles não têm noção de que sete pautas por dia não tem condições de fazermos bem feito” (SUJEITO $5)$.

Aspectos concretos, como questões familiares, ganhos financeiros e o número de pautas, são articulados de maneira a simbolizar o descontentamento em torno de dois temas básicos que surgem em várias manifestações: excesso de carga de trabalho e falta de reconhecimento financeiro. Esses temas surgem novamente quando, por exemplo, os funcionários se manifestam sobre a hora extra. Os sujeitos de pesquisa relatam um controle muito rígido, por parte da organização, do horário dos funcionários, mas, em um contexto de excesso de trabalho, afirmam que cumprir rigidamente a carga horária se torna uma dificuldade. É o que se constata na fala dos sujeitos.

31. "Eu reclamo muito do meu excesso de pauta. E tem aquela cobrança grande de não poder fazer hora extra, ter que dar conta de tudo no horário de trabalho" (SUJEITO 5).

O impedimento de realizar horas extras é visto pelos funcionários como uma questão legal e como algo que acarreta o excesso de trabalho, sendo que o reconhecimento financeiro, que também advém da hora extra, é previsto na legislação. Entretanto, como destacam Morgan, Frost e Pondy (1983) e Turner (1990), os mesmos símbolos podem ter diferentes significados de acordo com os grupos sociais, e isso foi observado no contexto investigado. As questões relacionadas a hora extra, baixos salários e excesso de trabalho são tratadas pelo gestor como características normais da cultura organizacional do XYZ e da rede de comunicação a qual ele pertence, como se observa nos fragmentos a seguir.

32. "Essa é uma filosofia aqui... todo mundo tem que fazer algo além da sua atividade em prol do lucro [...]. Produtos da rede são todos produtos rentáveis. Essa é uma premissa da empresa. Não trabalhamos com produtos que dão prejuízo” (SUJEITO 1).

As manifestações observadas ao longo da netnografia confirmam ser comum a associação entre o trabalho e o sofrimento, dentro de uma lógica pela qual isso é visto como necessário. O trecho a seguir deixa isso claro:

REAd | Porto Alegre - Edição 79 - N 3 - setembro/dezembro 2014 - p. 681-712 
Os usos do Facebook nas manifestações dos simbolismos organizacionais

33. "É isso! Cansada, exausta, mas tentando manter o foco! No pain no gain! :)" (SUJEITO 2).

Pode-se observar que os relatos sobre o que é tratado no chat on-line e o conteúdo que é exposto no Facebook, identificado por meio da netnografia, têm uma diferença significante: os assuntos tratados no chat são mais diretos e as reclamações quanto a excesso de trabalho, hora extra e salário são claras; já no Facebook, observam-se mensagens com um conteúdo simbólico mais implícito, que só são facilmente compreendidas por quem tem conhecimento do contexto em que os sujeitos estão inseridos, são reclamações veladas.

Nas postagens feitas no Facebook, percebe-se que os conteúdos, em sua maioria, estão ligados, basicamente, a fatos cotidianos, contatos com amigos e familiares, humor, entretenimento, opiniões e desabafos.

34. "Eu reclamo mesmo. Não sou cuscuz pra ficar abafado” (SUJEITO 5).

35. “Eu juro que queria ter um órgão no meu corpo que 'produzisse’ paciência. Meu cérebro não tá dando conta do recado” (SUJEITO 2).

Se, por um lado, a insatisfação está clara nesses fragmentos, por outro, apenas quem sabe do contexto específico de cada um reconhece a quais questões do cotidiano eles estão se referindo. Mas, de maneira geral, mesmo com essa barreira, ao se manifestarem sobre os conteúdos postados, os sujeitos começaram a dar indícios de preocupações com o excesso de exposição e a falta de privacidade. Segundo Boyd (2008), a possibilidade que o Facebook dá ao usuário de ver, na página inicial, as ações de seus contatos na rede, começou a gerar maior preocupação com essas questões.

36. “Tenho coisas pra falar que eu acho que muitas pessoas não vão concordar, vão olhar com outros olhos, vão olhar diferente. Então eu só posto coisas leves, superficiais, que não afetam ninguém” (SUJEITO 10).

Houghton e Joinson (2010) destacam que o receio com o excesso de exposição está relacionado ao fato de os “amigos" do Facebook pertencerem a grupos distintos, que envolvem amigos pessoais, familiares, contatos profissionais, entre outros. Esse fato foi relatado por um dos sujeitos.

37. "Eu acho que no Facebook não podemos ser a gente mesmo. O Facebook é uma página pessoal que você expõe suas opiniões, suas preferências, mas seu melhor amigo está vendo, mas seus pais também estão vendo, seu chefe está vendo... então eu acho que você nunca pode ser você” (SUJEITO 10).

REAd | Porto Alegre - Edição 79 - N 3 - setembro/dezembro 2014 - p. 681-712 
Os dois últimos fragmentos empíricos deixam claras as preocupações com o conteúdo das postagens e com a sua visibilidade. Essas tensões podem servir de explicação para o fato de que a troca de conteúdos simbólicos se dê mais pelo chat on-line do que pelo Facebook.

\subsection{Tensões relacionadas ao uso do Facebook pelos membros da organização}

A simbologia que envolve o Facebook - visto como um local de exposição, de visibilidade social - pode ser, em parte, a explicação para as tensões observadas em relação ao seu uso. Houghton e Joinson (2010) afirmam que as preocupações com a privacidade envolvendo o Facebook podem ser vistas por meio da perspectiva de seu uso para o controle das pessoas. Nesse sentido, os sujeitos evidenciaram o receio de postar conteúdos relacionados ao trabalho por medo da exposição e do alcance que isso teria. Observa-se um desconforto pelo fato de os gestores estarem na rede de contatos dos funcionários e isso faz com que estes se sintam vigiados.

38. "Eu confesso que, depois que o chefe se tornou meu amigo de Facebook, eu deixei ainda mais de publicar as coisas” (SUJEITO 8).

39. "Não sei se a empresa vigia, mas sei que não posso comentar isso, porque fulano pode ver. Às vezes, eu penso: 'ai, gente, que vontade de comentar alguma coisa', mas não comento por conta disso. Medo de eles verem. Me sinto um pouco vigiado sim” (SUJEITO 5).

40. “Às vezes uso pra desabafar [...], mas o que acontece: a chefe tem Facebook, então dificilmente eu vou falar alguma coisa específica do trabalho (SUJEITO 9).

É interessante notar que essa sensação de vigilância não está somente relacionada à presença dos gestores nas redes; há um entendimento compartilhado pelos sujeitos de que os próprios colegas de trabalho se vigiam.

41. "Eu acho que as próprias pessoas se vigiam, não só no ambiente de trabalho, mas fora também. E eu acho que é mais por isso que eu não uso tanto o Facebook" (SUJEITO 6).

42. “Como o Facebook tem uma exposição grande, se a gente fizer um comentário daqui, acaba criando uma proporção grande. Uma vez eu cheguei aqui na redação [...] fui na geladeira e tinha um pacotinho de uma amiga escrito 'favor não pegar'. Eu achei aquilo muito engraçado, tirei uma foto e 
Os usos do Facebook nas manifestações dos simbolismos organizacionais

botei no Face. Aí veio um colega e falou: 'pelo amor de deus, tira isso aí, como fica a imagem da empresa você falando que roubam comida na geladeira?’. Não me atentei pra isso. Fui lá e tirei. Depois desse dia, eu passei a ter mais cuidado com as coisas que eu coloco aqui da empresa” (SUJEITO 5).

43. “Teve uma vez uma menina aqui que postou uma foto de biquíni... aí eu cheguei pra ela e falei: olha só, um monte de gente vai ver seu Facebook. É desse jeito que você quer ser vista? Ou você quer aparecer como alguém sério?” (SUJEITO 1).

Observa-se, portanto, que parte dos funcionários evita o contato pessoal e a troca de conteúdo via Facebook por acreditar que está sendo vigiada por gestores, colegas de trabalho e outras pessoas de fora. Podem-se relacionar essas construções com a ideia de panóptico, discutida por Foucault (2007) para destacar os dispositivos de vigilância das sociedades disciplinares, que implicam a organização dos indivíduos mediante a interiorização do controle. O objetivo seria induzir o indivíduo a um estado de permanente vigilância que assegurasse o funcionamento do poder. "Quem está submetido a um campo de visibilidade, [...] retoma por sua conta as limitações do poder; [...] desempenha simultaneamente os dois papéis: torna-se o princípio da sua própria sujeição” (FOUCAULT, 2007, p. 168).

Segundo Deleuze (1992), a forma de poder instaurada após o século XX caracterizavase pelo controle contínuo e difuso. A internet seria parte do panóptico contemporâneo. Deleuze (2000, p. 220) classificou esse momento de “sociedade de controle”.

Nesse sentido, no discurso dos próprios gestores no contexto investigado, há indícios de vigilância de funcionários por meio do Facebook e manifestações sobre o receio pela divulgação de informações estratégicas (CONSTANT; SPROULL; KIESLER, 1996; WELLMAN, 1996) e pela queda na produtividade (CARDOSO, 2009). Como observado por Ribeiro (2000), a ação gestora encontra, nesses locais, suporte para sua difusão e legitimação.

44. "Uma vez uma pessoa faltou... mentira! Tava no Facebook, postou foto, estava em São Paulo, na balada. Entendeu? Eu não vou entrar no Facebook pra buscar isso, mas as pessoas sacam! Então não é monitorar o Facebook, mas acho que a gente precisa definir algumas regras” (SUJEITO 1).

REAd | Porto Alegre - Edição 79 - N 3 - setembro/dezembro 2014 - p. 681-712 
45. “Uma vez, a gente fez uma reunião aqui porque alguém postou alguma coisa aqui da redação. Aí eu falei: ‘não, isso eu não quero’. Não tem que levar coisas daqui pro Facebook. Eu acho isso negativo” (SUJEITO 1).

Esse discurso organizacional, de preocupação com informações estratégicas sendo expostas no Facebook, foi transmitido aos funcionários em uma reunião. De acordo com os sujeitos, esse fato aumentou o medo da vigilância e fez com que eles passassem a reproduzir esse discurso, legitimando a ação de controle do gestor (RIBEIRO, 2000).

46. “Depois dessa reunião, mudou. Agora pouca gente usa [...]. Foi uma reunião bem geral, porque tinha gente que ficava falando coisas do trabalho no Facebook, tipo: 'estamos apurando tal coisa'. E isso não se faz. Então era pra deixar o pessoal ligado” (SUJEITO 9).

47. "O chefe mesmo esses dias falou pra gente que o Facebook, mesmo sendo para uso pessoal, você está ali como funcionário do XYZ, as pessoas sabem que você trabalha aqui, e acabam não separando” (SUJEITO 5).

48. “As pessoas de fora daqui ficam comentando que a gente está no Facebook no horário de trabalho. Se eles me veem no Facebook no horário de trabalho, vão pensar o quê? Que eu não faço nada!” (SUJEITO 9).

Nos relatos citados acima, é possível observar que há uma incorporação, por parte dos funcionários, do discurso organizacional, uma vez que, após a reunião feita pelos gestores, os funcionários passaram a acreditar que o que eles postam no Facebook está diretamente ligado ao conteúdo do trabalho. Isso demonstra que o uso do Facebook promove uma quebra do limite entre os espaços organizacionais e pessoais.

Essa constatação, em conjunto com as demais evidências discutidas até aqui, revela que os usos do Facebook pelos membros do jornal on-line XYZ levam a manifestações veladas dos simbolismos organizacionais. Há uma resistência quanto a usá-lo livremente e, quando usado, há a preocupação em considerar as implicações, na empresa, das possíveis interpretações do que foi postado. É estabelecida uma espécie de autocensura pela força do panóptico, e os usuários buscam antecipar as interpretações, por parte de outros, dos simbolismos em jogo. Nesse processo, eles definem se convém fazer a postagem desejada, eliminar uma postagem já publicada ou apresentá-la por meio de manifestações que só podem ser interpretadas e compreendidas, de maneira exata, por quem realmente tem conhecimento do contexto ao qual a manifestação se refere. Nesse sentido, o próprio uso do Facebook pelos

REAd | Porto Alegre - Edição 79 - N 3 - setembro/dezembro 2014 - p. 681-712 
Os usos do Facebook nas manifestações dos simbolismos organizacionais

demais membros organizacionais interfere no uso de cada um dos funcionários, devido às implicações decorrentes das possíveis interpretações dos simbolismos em jogo.

\section{CONSIDERAÇÕES FINAIS}

Ao retomar o objetivo deste artigo, que é compreender a relação entre os usos do Facebook pelos membros do jornal on-line XYZ e as manifestações dos simbolismos organizacionais, pode-se afirmar que foi evidenciado um processo simbólico de interpretação das ações, no qual cada usuário da rede busca antecipar as interpretações dos outros usuários em relação aos simbolismos organizacionais para definir como vai se manifestar, ou se deve fazer isso, em alguns casos até apagando postagens já publicadas.

Neste artigo, atribui-se à força do panóptico, no qual o Facebook se insere, a explicação para esse comportamento. Entretanto, como revela Foucault (2007), sempre há resistência e, a despeito dessa força, características interpretadas como negativas pelos sujeitos, como o excesso de trabalho, o qual gera uma construção coletiva de interdependência e legitima a interação via Facebook no cotidiano.

A pessoa não é apenas submissa ao contexto, ela tem espaço para agir legitimamente até além dos limites interpretados como os permitidos na organização, mas o panóptico vai estar lá, deixando claro que se trata de uma resistência e que há um preço a ser pago. Portanto, a pessoa não vai sempre optar pelo caminho da resistência, pois compreende pelo menos parte das consequências disso. Ela vivencia o cotidiano como um contexto no qual compreende o ambiente e atua de acordo com essa compreensão (VERGARA; CALDAS, 2005).

No cotidiano do XYZ, os usos descritos pelos sujeitos de pesquisa - entretenimento (ELLISON; STEINFIELD; LAMPE, 2006); comunicação e manutenção das relações (DWYER; HILTZ; PASSERINI, 2007); trocas de informações sobre o cotidiano por meio da navegação entre os perfis (GOLDER; WILKINSON; HUBERMAN, 2007); reforço de conexões (SUBRAHMANYAM et al., 2008); e acesso a informações profissionais (SHIRKY, 2012) - demonstraram que o Facebook, dentro dos limites já mencionados, é um canal de comunicação e troca simbólica entre eles. Esse argumento vai ao encontro do entendimento de Lyon (2002), que destaca que os relacionamentos mediados por algum tipo de tecnologia viabilizam a troca de conteúdos simbólicos em determinado ambiente.

Também com foco nas tecnologias, McLuhan e Powers (1993) indicaram que o ambiente recebe interferência dos meios de comunicação, com destaque para os meios

REAd | Porto Alegre - Edição 79 - N 3 - setembro/dezembro 2014 - p. 681-712 
baseados em tecnologias eletrônicas com grandes velocidades e articulados em uma rede global, como se o mundo fosse uma aldeia com ampla comunicação entre os seus habitantes. Segundo os autores, a televisão, o computador, o satélite, entre outras tecnologias articuladas, levam a várias possibilidades inovadoras, desde a disponibilização do acervo de bibliotecas inteiras até informações transmitidas ao vivo e adaptadas à necessidade de usuários específicos. Neste estudo, ficou evidente um processo no qual a tecnologia do Facebook interfere no ambiente organizacional, justamente por viabilizar essa rede de troca de informações em alta velocidade, capaz de armazenar o conteúdo das comunicações.

Tais características fazem parte da natureza do meio de comunicação aqui investigado. Essa natureza marca o ser humano, na medida em que o meio de comunicação é uma extensão do corpo humano, ampliando os sentidos deste, em uma dinâmica na qual os meios se constituem em artefatos culturais da sociedade, com o potencial de levá-la à inovação (MCLUHAN, 1971).

Para McLuhan e Powers (1993), o reconhecimento dessa dinâmica exige romper com a visão linear da comunicação, que se centra em conteúdos e separa ação e pensamento. Para os autores, deve-se reconhecer a influência de um meio de comunicação sobre o outro, compondo um ambiente, que também é um meio, pelo qual transitam conteúdos em uma construção não linear, pois este recebe múltiplas interferências dos meios que o perpassam. Esse entendimento coaduna-se com o fato de que as trocas simbólicas identificadas neste estudo não se restringem ao uso apenas do Facebook no XYZ, como se essa rede fosse um meio isolado, mas incluem também o uso simultâneo de vários outros meios.

$\mathrm{Na}$ análise dos dados, observou-se que as trocas simbólicas também ocorrem por meio de outras redes sociais digitais, como o e-mail e o chat on-line. Ao analisar o conteúdo das mensagens, foi possível observar que há diferenças entre os tipos de usos nessas mídias: os assuntos tratados no chat são mais diretos e as reclamações quanto a excesso de trabalho, hora extra e salário são claras; já no Facebook, observam-se mais mensagens que envolvem interpretações implícitas, veladas, que permitem a compreensão apenas pelas pessoas que conhecem o contexto no qual aqueles sujeitos estão inseridos.

Esse espaço para a pessoa completar a mensagem, evidenciado na análise dos dados, insere incontestavelmente o Facebook na tipologia de meio de comunicação cool, tal como definido por McLuhan (1971), com todas as suas implicações, ou seja, um maior comprometimento e integração das pessoas em torno do meio. Isso não quer dizer que elas

REAd | Porto Alegre - Edição 79 - N 3 - setembro/dezembro 2014 - p. 681-712 
Os usos do Facebook nas manifestações dos simbolismos organizacionais

terão, necessariamente, maior comprometimento e integração com a organização estudada, inclusive o efeito pode ser o oposto. Segundo o autor, o comprometimento e a integração se dão em termos da sociedade, com a ruptura dos segredos entre grupos sociais. Nesse contexto, os membros organizacionais têm o potencial para reconhecer e se opor às práticas organizacionais inadequadas; um dos caminhos para isso é denunciá-las e desafiá-las, como se evidenciou na análise dos dados deste estudo.

Tais manifestações, como ressaltam McLuhan e Fiore (1969), não devem ser confrontadas apenas com o significado do seu conteúdo, pois a natureza do meio de comunicação tem mais impacto na sociedade do que o conteúdo em si mesmo. Ou seja, o uso diferenciado do Facebook em relação aos outros meios de comunicação disponíveis na organização pode ser explicado pelo significado compartilhado pelos sujeitos de que essa mídia está muito ligada à exposição e à visibilidade social. Dessa forma, criou-se um receio coletivo de utilizar essa rede social, pois os funcionários acreditam que estão sendo vigiados não só pelos gestores, mas também pelos seus colegas de trabalho e pessoas de fora dele. Aqui o controle se faz presente em torno dos usos do Facebook (HOUGHTON; JOINSON, 2010).Por sua vez, o medo da vigilância mútua demonstra a interpretação dos funcionários sobre o contexto organizacional do XYZ: um local onde todos são controlados em prol da produtividade e do lucro.

Portanto, ao voltar à pergunta principal à qual este artigo pretende responder - como o uso do Facebook no cotidiano das pessoas dentro e fora do jornal on-line XYZ articula-se às manifestações dos simbolismos organizacionais? - pode-se afirmar que a interpretação de boa parte dos símbolos organizacionais, como salário, hora extra e excesso de trabalho, ocorre com mais frequência durante o uso do chat on-line do que pelo Facebook. Isso se explica da seguinte forma: apesar de estar presente em ambas as situações de comunicação, em relação ao Facebook, o medo da vigilância - quanto a cumprir horários e não fazer horas extras; quanto a aceitar o excesso de trabalho; quanto a não reclamar de baixos salários - manifestouse de maneira mais acentuada, dada a maior visibilidade do que é postado. Trata-se, contudo, de uma vigilância velada, em prol da manutenção daquilo que os gestores acreditam ser parte da cultura organizacional: o foco no lucro. É por causa dessa vigilância que os sujeitos buscam um espaço mais privado para falar de certas questões: o chat.

O Facebook não deixa de ser utilizado, mas seu uso é ainda mais autocensurado e exige artimanhas com foco na interpretação dos outros usuários, tais como postar manifestações 
com conteúdos simbólicos implícitos no lugar dos explícitos ou postar algo e depois apagar para demonstrar (des)respeito aos limites organizacionais. Nesse sentido, o uso do Facebook é também a resistência em relação ao contexto organizacional e às imposições na prescrição de determinados simbolismos organizacionais, como a cultura organizacional com foco excessivo no lucro, no caso do XYZ.

Esse entendimento remete à convicção de que cabe uma análise mais aprofundada das redes sociais digitais por meio de estudos com um foco específico: a perspectiva do controle (HOUGHTON; JOINSON, 2010), na sociedade do controle (DELEUZE, 2000), e as possibilidades de resistir a ele por meio dos usos das redes sociais digitais. A identificação de elementos associados a essa perspectiva faz parte das contribuições deste artigo, mas um aprofundamento na sua análise e discussão fogem do escopo do objetivo proposto. Portanto, sugere-se que essa contribuição seja explorada em estudos futuros.

Com base no que foi aqui discutido, cabe ressaltar a importância de tais estudos futuros não considerarem o Facebook, ou qualquer outra rede social digital, como um meio isolado, em uma lógica de análise linear da comunicação, pois isso reduziria o potencial para se tratar o assunto. Indo ao encontro das ideias de McLuhan (1971), a discussão aqui desenvolvida ressalta a importância de analisar as redes sociais digitais em termos das relações que elas mantêm com os diversos meios de comunicação, alguns dos quais contidos nas próprias redes, pois elas, em si mesmas, são meios compostos por outros meios.

\section{REFERÊNCIAS}

AKTOUF, O. O simbolismo e a cultura da empresa: dos abusos conceituais às lições empíricas. In: CHANLAT, J. F. (Org.). O indivíduo nas organizações: dimensões esquecidas. São Paulo: Atlas, 1994. v. 2, p. 39-79.

ALBUQUERQUE, F. M. F. de; PEREIRA, R. C. F.; BELLINI, C. G. P. Do repertório de comportamentos do consumidor: retaliação e vingança no ciberespaço. Revista de Administração da Universidade de São Paulo, São Paulo, v. 46, n. 2, p. 135-149, abr./maio/jun. 2011.

ALVESSON, M.; BERG, P. O. Corporate culture and organizational symbolism. Berlin: de Gruyter, 1992.

BARDIN, L. Análise de conteúdo. Lisboa: Edições 70, 2002.

REAd | Porto Alegre - Edição 79 - N 3 - setembro/dezembro 2014 - p. 681-712 
Os usos do Facebook nas manifestações dos simbolismos organizacionais

BERGER, P. L.; LUCKMANN, T. A construção social da realidade. Petrópolis: Vozes, 1978.

BLUMER, H. Symbolic interacionism: perspective and method. California: University of California Press, 1969.

BOYD, D. M. Facebook's privacy trainwreck: exposure, invasion and social convergence. The International Journal of Research into New Media Technologies, Luton, v. 14, n. 1, p. 13-20, 2008.

BOYD, D. M.; ELLISON, N. B. Social network sites: definition, history and scholarship. Journal of Computer-Mediated Communication, University Park, Pennsylvania, v. 13, n. 1, p. 210-230, Oct. 2007.

BRETAS, B. Interações cotidianas. In: GUIMARÃES, C.; FRANCA, V. (Org.). Na mídia, na rua: narrativas do cotidiano. Belo Horizonte: Autêntica, 2006. p. 29-42.

CARDOSO, C. G. Novas formas de comunicação organizacional na sociedade da informação. In: KUNSCH, M. (Org.). Comunicação organizacional: histórico, fundamento e processos. São Paulo: Saraiva, 2009. v. 1, p. 355-366.

CARVALHO, V. Interacionismo simbólico: origens, pressupostos e contribuições aos estudos organizacionais. In: ENCONTRO DA DIVISÃO DE ESTUDOS ORGANIZACIONAIS DA ANPAD, 6., maio 2010, Florianópolis. Anais... Rio de Janeiro: ANPAD, 2010. 1 CD-ROM.

CASTELLS, M. A sociedade em rede. Rio de Janeiro: Zahar, 1999.

COLEMAN, J. S. Social capital and the creation of human capital. In: CALHOUN, C et al. (Ed.). Contemporary sociological theory. Oxford: Blackwell Publishing Ltd, 2002. p. 110117.

CONSTANT, D.; SPROULL, L.; KIESLER, S. The kindness of strangers: the usefulness of electronic weak ties for technical advice. Organization Science, Catonsville, v. 7, n. 2, p.119135, 1996. 
CORRÊA, E. S. Comunicação digital e novas mídias institucionais. In: KUNSCH, M.

Comunicação organizacional: histórico, fundamento e processos. São Paulo: Saraiva, 2009. v. 1, p. 317-336.

DELEUZE, G. Conversações: 1972-1990. São Paulo: Editora 34, 1992.

DELEUZE, G. Uma vida filosófica. São Paulo: Editora 34, 2000.

DWYER, C.; HILTZ, S. R.; PASSERINI, K. Trust and privacy concern within social network sites: a comparison of Facebook and MySpace. 2007. Trabalho apresentado na 13th Americas Conference on Information Systems, Keystone, Colorado, 2007.

ELLISON, N. B.; STEINFIELD, C.; LAMPE, C. Spatially bounded online social networks and social capital: the role of Facebook. 2006. Trabalho apresentado na 56th Annual Conference of the International Communication Association, Dresden, 2006.

ELLISON, N. B.; STEINFIELD; C., LAMPE, C. The benefits of Facebook “friends": social capital and college students' use of online social network sites. Journal of ComputerMediated Communication, University Park, Pennsylvania, v. 12, n. 4, p. 1143-1168, July 2007.

FOUCAULT, M. Vigiar e punir: nascimento da prisão. Petrópolis: Vozes, 2007.

GARTON, L.; HAYTHORNTHWAITE, C.; WELLMAN, B. Studying online social networks. Journal of Computer-Mediated Communication, University Park, Pennsylvania, v. 1, n. 3, June 1997.

GIOIA, D. A. Symbols, scripts and sensemaking: creating meaning in the organizational experience. In: SIMS, H. P.; GIOIA, D. A. (Ed.). The thinking organization. San Francisco: Jossey-Bass Publishers, 1986. p. 49-74.

GODOY, A. S. Pesquisa qualitativa: tipos fundamentais. Revista de Administração de Empresas. São Paulo, v. 35, n. 3, p. 20-29, mai./jun. 1995.

GOLDER, S. A.; WILKINSON, D.; HUBERMAN, B. A. Rhythms of social interaction: messaging within a massive online network. 2007. Trabalho apresentado na 3rd International Conference on Communities and Technologies, East Lansing, 2007. 
Os usos do Facebook nas manifestações dos simbolismos organizacionais

HAYTHORNTHWAITE, C. Social networks and Internet connectivity effects. Information, Communication \& Society, v. 8, n. 2, p. 125-147, June 2005.

HOUGHTON, D. J.; JOINSON, A. N. Privacy, social networks sites and social relations. Journal of Technology in Human Services, v. 28, n. 1-2, p. 74-94, 2010.

JAIME JR., P. Um texto, múltiplas interpretações: antropologia hermenêutica e cultura organizacional. In: CAVEDON, N.; LENGLER, J. (Org.). Pós-modernidade e etnografia nas organizações. Santa Cruz do Sul: EDUNISC, 2005. p. 145-169.

KOZINETS, R. V. Netnography: doing ethnographic research online. London: Sage, 2010.

KOZINETS, R. V. On netnography: initial reflections on consumer research investigations of cyberculture. Advances in Consumer Research, Provo, v. 25, p. 366-371, 1998.

LYON, D. Cyberspace: beyond the information society? In: ARMITAGE, J.; ROBERTS, J. (Ed.). Livin with cyberspace. Bodmin: 2002. p. 21-33.

MAINES, D. R. Social organization and social structure in symbolic interactionist thought. Annual Review of Sociology, Palo Alto, v. 3, p. 235-259, 1977.

MARCHIORI, M. R. As interconexões entre cultura organizacional e comunicação. In: KUNSCH, M. Comunicação organizacional: linguagem, gestão e perspectivas. São Paulo: Saraiva, 2009. v. 2, p. 293-320.

MCLUHAN, M. Os meios de comunicação como extensões do homem. 3. ed. São Paulo: Cultrix, 1971.

MCLUHAN, M.; FIORE, Q. O meio são as massa-gens. Rio de Janeiro: Record, 1969.

MCLUHAN, M.; POWERS, B. R. La aldea global: transformaciones en la vida y los medios de comunicación mundiales en el siglo XXI. 2. ed. Barcelona: Gedisa, 1993.

MENDONÇA, J. R. C. Interacionismo simbólico: uma sugestão metodológica para a pesquisa em Administração. Revista Eletrônica de Administração, Porto Alegre, ed. 26, v. 8, n. 2, mar.-abr. 2002. 
MINAYO, M. C. S. O desafio do conhecimento: pesquisa qualitativa em Saúde. São Paulo: Hucitec-Abrasco, 1999.

MORGAN, G.; FROST, P.; PONDY, L. Organizational symbolism. In: PONDY, L. et al. (Ed.). Organizational symbolism. Connecticut: Jay Press, 1983. p. 3-35.

NADKARNI, A.; HOFMANN, S. G. Why do people use Facebook? Personality and Individuals Differences, Philadelphia, v. 52, p. 243-249, 2012.

OLIVEIRA JUNIOR, V. J. de. Social media tips: o que os manuais corporativos têm a dizer sobre o uso de redes sociais digitais? In: SIMPÓSIO NACIONAL ABCiber, 5., nov. 2011, Florianópolis. Anais... Florianópolis: UFSC, 2011.

PEREIRA, M. A. Internet e mobilização política - os movimentos sociais na era digital. Teoria \& Sociedade, Belo Horizonte, v. 18, n. 2, p. 10-33, 2010.

RECUERO, R. Redes sociais na internet. Porto Alegre: Sulina, 2010.

RHEINGOLD, H. The virtual community: homesteading on the electronic frontier. Cambridge: Addison-Wesley Publishing Company, 1993.

RIBEIRO, A. C. T. La naturaleza del poder: técnica y acción social. Interface: Comunicação, Saúde e Educação, Botucatu, v. 4, n. 7, p. 13-24, 2000.

SHIRKY, C. A cultura da participação: criatividade e generosidade no mundo conectado. Rio de Janeiro: Zahar, 2011.

SHIRKY, C. Lá vem todo mundo: o poder de organizar sem organizações. Rio de Janeiro: Zahar, 2012.

SPROULL, L.; KIESLER, S. Connections: new ways of working in the networked organization. Cambridge: MIT Press, 1991.

SUBRAHMANYAM, K.; REICH, S. M.; WAECHTER, N.; ESPINOZA, G. Online and offline social networks: use of social networking sites by emerging adults. Journal of Applied Developmental Psychology, Philadelphia, v. 29, n. 6, p. 420-433, 2008.

REAd | Porto Alegre - Edição 79 - Nº 3 - setembro/dezembro 2014 - p. 681-712 
Os usos do Facebook nas manifestações dos simbolismos organizacionais

TURNER. B. A. Introduction. In: TURNER, B. A. (Ed.). Organizational symbolism. New York: De Gruyter, 1990. p. 1-11.

VERGARA, S. C.; CALDAS, M. P. Paradigma interpretacionista: a busca da superação do objetivismo funcionalista nos anos 1980 e 1990. Revista de Administração de Empresas, São Paulo, v. 45, n. 4, p. 66-72, 2005.

WEBER, M. The theory of social and economic organization. New York: The Free Press, 1997.

WELLMAN, B. Computer networks as social networks: collaborative work, telework and virtual community. Annual Reviews of Sociology, Palo Alto, v. 22, p. 213-238, 1996. 